\title{
Implementasi karakter kreatif dalam organisasi ikatan jamaah majelis ta'lim Al-Barkah untuk memakmurkan masjid
}

\author{
Hanis Asmar ${ }^{a, 1}$, Yogi Nugraha ${ }^{b, 2}$, Erwin Susanto ${ }^{c, 3}$ \\ a,b,c Pendidikan Pancasila dan Kewarganegaraan, Universitas Buana Perjuangan Karawang, Indonesia \\ ${ }^{1}$ pk16.hanisasmar@mhs.ubpkarawang.ac.id* \\ *korespondensi penulis
}

ABSTRAK

Penelitian ini bertujuan untuk mengetahui mengenai Implementasi Karakter Kereatif Organisasi Ikatan Jamaah Majelis Ta'lim Al-Barkah Untuk Memakmurkan Masjid. Penelitian ini merupakan jenis penelitian kualitatif dengan metode deskriptif. Teknik penelitian yang digunakan melakukan observasi lapangan dan wawancara dengan Ketua ljma, Wakil Ketua Ijma, dan tiga Anggota Remaja Ijma. Subjek penelitian ini adalah Ketua Organisasi Ijma, Wakil Ketua Organisasi Ijma, dan Anggota Remaja Organisasi ljma. Hasil penelitian ini menunjukan dengan adanya organisasi ijma dengan mengimplementasikan karakter kreatif bisa melakukan suatu perubahan mulai dari memakmurkan masjid. Alasan melakukan penelitian ini karena adanya organisasi ijma yang bisa membawa perubahan dengan memakmurkan kembali masjid yang sudah lama tidak dipergunakan kegiatan keislamian dan sekarang mulai ramai lagi digunakan untuk kegiatan-kegiatan keislamian. Dalam penelitian ini dapat diperoleh implementasi karakter kreatif dalam kegiatan yang dilakukan oleh organisasi ijma mulai dari kegiatan yang lebih bermanfaat yang belum pernah dilakukan sebelumny. Sehingga dapat disimpulkan implementasi karakter kreatif dalam kegiatan organisasi ljma dapat memberikan perubahan dalam memakmurkan masjid.

\section{ABSTRACT}

The research aims to investigate the implementation of creative character the of Al-Barkah Majlis Ta'lim Jama'ah Association to prosper the mosque. This research is a qualitative research with a descriptive method. The techniques of research used are conducted direct observations and interviews with the head, the deputy head, and the three members of AlBarkah Majlis Ta'lim Jama'ah Association. The data collection techniques used in this research are direct observations and interviews with the subjects of the research. The result of the research showed that implementing creative character could bring a change to the organization. It brought prosperity to the mosque. This research is based on the fact that AlBarkah Majlis Ta'lim Jama'ah Association could make a change by rebuilding the prosperity of the mosque that had not been used for Islamic activities in a while. Now the mosque is starting to be packed with Islamic activities again. From the conducted research, several activities are done by of Al-Barkah Majlis Ta'lim Jama'ah Association in implementing creative character. Therefore, it can be concluded that the implementation of creative character in the activities of Al-Barkah Majlis Ta'lim Jama'ah Association contributes to prosper the mosque.
Informasi Artikel

Diterima:28 Januari 2021

Disetujui: 15 Maret 2021

Kata kunci:

Karakter kreatif

Organisasi majelis ta'lim

\section{Article's Information}

Received: 28 Januari 2021

Accepted: 15 Maret 2021

Keywords:

Creative character

Majelis ta'lim organization

\section{Pendahuluan}

Implementasi karakter kreatif dalam kegiatan organisasi merupakan suatu hal yang sangat penting dalam berorganisasi terutama dalam kegiatan organisasi ijma, agar terciptanya perubahan dengan tujuan yang sama. Menurut Purhantara (2012: 154-155), karakter atau kreativitas merupakan kemampuan untuk mengembangkan ide-ide baru dan menemukan cara baru untuk memandang masalah menjadi peluang. Kreatif atau kreativitas memegang peran yang sangat sentral didalam upaya-upaya baik individu maupun organisasi didalam mengoptimalkan potensi dirinya untuk mengefektifkan kinerja dalam rangka memberikan kepuasan pada semua stekholder (masyarakat). 
Kreatif itu merupakan karakter yang sangat penting baik dalam individu maupun dalam organisasi, karena dengan adanya kreatif bisa membawa seseorang atau sekelompok orang menemukan cara atau ide dalam mencari solusi dalam suatu masalah sehingga merubah suatu keadaan menjadi lebih baik dan mampu menemukan jalan keluar dalam suatu permasalahan dan organisasi ijma mempunyai suatu tujuan, tujuan disini adalah untuk memakmurkan masjid yang sudah tiga tahun tidak dipergunakan dengan kegiatan keagamaan selain shalat berjamaah.

Maka dari itu organisasi ijma merupakan organisasi yang ingin melakukan perubahan dengan tujuan untuk memakmurkan kembali masjid dengan mengimplementasikan karakter kreatif dalam kegiatan-kegiatan keagamaan yang terkoordinir oleh ketua oraganisasi yang bekerjasama bersama dengan para anggota organisasi ijma, yang sudah direncanakan, secara tersusun untuk mencapai suatu tujuan. Menurut Ali (2018: 11), karakter adalah sifat kejiwaan, akhlak atau budi pekerti yang menjadi ciri khas seseorang atau sekelompok orang. Karater merupakan nilai-nilai perilaku manusia yang berhubungan dengan Tuhan Yang Maha Esa, diri sendiri, sesama manusia, lingkungan dan kebangsaan terwujud dalam pikiran, sikap, perasaan, perkataan, dan perbuatan berdasarkan normanorma agama, hukum, tata krama, budaya, dan adat istiadat. Karakter merupakan hal sangat penting dalam menjalankan kehidupan khususnya kehidupan bersosial karena dalam kehidupan sosial adanya suatu hubungan manusia dengan manusia, individu dengan individu, individu dengan kelompok, maka dari itu diperlukan hubungan baik dengan tuhan, dan berhubungan baik juga dengan manusia, begitupun dalam organisasi ijma, karena organisasi ijma merupakan organisasi yang sama-sama memiliki tujuan yang sama untuk melakukkan perubahan dalam meningkatkan kemakmuran masjid. Menurut Duha (2018: 2) bahwa organisasi merupakan kesatuan yang terbentuk oleh beberapa orang yang memiliki sedikit atau semua kesamaan tentang latar belakang, identitas, harapan, dan berbagai hal lainnya untuk mencapai tujuan bersama secara bersama-sama. Didalam organisasi bertindak, bekerja berdasarkan tugas dan fungsi masing-masing, dan saling berkoordinasi dengan bagian lain tanpa mengintervensi (campur tangan), dan tumpang tindih kewajiban dengan orang lain. begitupun Organisasi ijam merupakan kesatuan yang terlahir dari dua orang atau lebih dengan tujuan yang sama dengan cara disengaja dan terstruktur baik dengan bekerja sama dan bersama-sama untuk melakukan perubahan dalam lingkungan sosial. Ketika itu di tahun dua ribu enam belas (2016) pernah ada organisasi Ikatan Remaja Majelis Talim Al-Barkah (IRMA), dengan adanya irma mulai ada kegiatan keagamaan, itu pun hanya pengajian rutin bapak-bapak yang dilakukan setiap malam jumat, dan hanya bertahan sekitar enam bulan karean terhalang bulan ramadhan, kegiatan pengajian tidak dilakukan lagi sampai bulan juli tahun dua ribu sembilan belas (2019) dan organisasi irma pun sudah tidak ada lagi karena banyaknya anggota irma yang menikah, dan masjid pun sepi hanya digunakkan untuk shlat berjamaah saja. Setelah terhalang beberapa bulan tepatnya di bulan itu pun pada tanggal empat belas (14) Juli lahir lah Ikatan Jamaah Majelis Ta'lim Al-Barkah (IJMA) dengan anggota yang kebanyakan sudah berumah tangga dengan sedikit anggota remaja, tetap menghidupkan kembali masjid dengan kegiatan keagamaan yang menampilkan kekreatifan atau ide-ide baru. Organisais ijma merupakan organisasi yang termasuk organisasi baru dengan tujuan baru yang mempunyai banyak permasalahan baru mulai dari sumber daya manusi, kurang nya partisispasi masyarakat, kurangnya material atau dana yang akan digunakan organisasi ijma ketika akan melakukan kegiatan-kegiatan.

Salah satu upaya untuk memakmurkan kembali masjid, organisasi ijam melakukan kegiatankegiatan yang berbeda dari sebelumnya, dengan ide-ide baru yang kreatif dan lebih bermanfaat. Menurut Ghifar dkk. (2019: 781), bahwa kreatif atau kreativitas adalah mewujudkan ide-ide baru dalam bekerja, memecahkan masalah dan melakukan tindakan-tindakan inovatif dengan pendekatan yang unik untuk memecahkan masalah dengan menggunakan teknologi dan sumber daya lainnya ke dalam proses yang unik yang membedakan prestasi dari setiap orang dalam organisasi. Cara untuk melakukan kegiatan yang dilakukan oleh organisasi ijma disetiap para anggota dengan ketua dengan cara melakuakan sesuatu hal kecil yang dibiasakan seperti ketika melakukan suatu kegiatan pasti dilakukan musyawarah terlebih dahulu membebaskan untuk menyampaikan pendapat sehingga 
menimbulkan ide-ide baru dan dapat meciptakan kegiatan-kegiatan yang kreatif yang dapat memakmurkan masjid.

Berdasarkan permasalahan diatas peneliti menemukan beberapa faktor permasalahan yang terjadi yaitu ketidak makmurkan masjid, salah satunya yaitu kurangnya kegiatan yang dapat memakmurkan masjid. Hal ini dikarenakan organisasi yang terdahulu tidak melaakukan kegiatan yang kreatif, sehingga berkurangnya kemakmuran masjid. Oleh karena itu terbentuklah organisasi baru yaitu organisasi ikatan jamaah majelis talim Al-Barkah (IJMA) yang memberikan suasan atau memberikan gebrakan yang lebih kreatif yang dapat meningkatkan kemakmuran masjid. Masjid yang dimana hanya digunakan untuk shlat berjamaah saja, sekarang ditambah dengan kegiatan yang lebih bermanfaat sehingga dapat meningkatkan kemakmuran masjid. Melihat permasalahan yang telah diuraikan, maka peneliti melakukan penelitian yang berjudul "Implementasi Karakter Kreatif Organisasi Ikatan Jamaah Majelis Ta'lim Al-Barkah Untuk Memakmurkan Masjid”.

\section{Metode}

Pendekatan yang peneliti gunakan ialah pendekatan kualitatif dengan metode deskriptif. Penelitian ini dilakukan pada organisasi majelis ta'lim di Masjid Ta'lim Al-Barkah, Dusun Rawabambu, RT/RW 004/002, Desa Sindangmulya, Kec Kutawaluya, Kabupaten Karawang. Adapun subjek dalam penelitian ini terdiri dari ketua organisasi, wakil ketua organisasi, dan anggota organisasi. Kemudian teknik pengumpulan data yang digunakan ialah observasi, wawancara, dan studi dokumentasi.

\section{Hasil dan Pembahasan}

Berdasarkan data yang diperoleh melalui observasi, wawancara, dan studi dokumentasi. Pada bagian ini akan dikemukakan hasil dan pembahasan terkait karakter kreatif dalam kegiatan organisasi ikatan jamaah majelis ta'lim Al-Barkah untuk memakmurkan masjid yaitu sebagai berikut.

Kegiatan Organisasi khususnya lingkup Organisasi Majelis Talim dalam mengembangkan atau menerapkan karakter kreatif dalam suatu kegiatan sangatlah diperlukan. Sesuai dengan pernyataan Purhantara (2012) menjelaskan bahwa "karakter atau kreativitas merupakan kemampuan untuk mengembangkan ide-ide baru dan menemukan cara baru untuk memandang masalah menjadi peluang. Kreatif atau kreativitas memegang peran yang sangat sentral dan penting didalam upayaupaya baik individu maupun organisasi didalam mengoptimalkan potensi dirinya untuk mengefektifkan kinerja dalam rangka memberikan kepuasan pada semua stekholder. Upaya ini diterjemahkan sebagai upaya untuk mencari cara-cara baru di dalam mencari solusi atas problem yang terjadi, baik yang bersumber dari optimalisasi potensi dari dalam (inner-power) maupun dikarenakan oleh tekanan dari faktor ekternal organisasi" (hal. 154-155). Maka dari itu kegiatan atau kinerja yang kreatif dalam seperti halnya di organisasi ijma dalam melakukakan kegiatan kreatif sangat penting karena dapat memberikan suasana yang berbeda dengan organisasi lain. Memberikan cara atau ide baru dari organisasi sebelumnya, seperti menampilkan kegiatan peringatan hari besar islam (PHBI) dengan menampilkan kegiatan yang berbeda yaitu seperti adanya santunan, penampilan alat musik terbangan, adanya drama rintihan anak yatim piatu, melakukan pembuatan proposal dalam kegiatan karena kurangnya dana untuk melakukan kegiatan, membuat gambar bener atau baliho untuk mengumumkan akan diadankannya kegiatan, membuat undangan ke majelis-majelis ta'lim lain agar menambah erat ikatan persaudaraan antar muslim, dan organisasi ijma ini dapat menciptakan hubungan baik terhadap lingkungan masyarakat. Hal ini sejalan dengan pandangan Kurnia (2015) menjelaskan bahwa "kreatif atau kreativitas merupakan kemampuan umum untuk menciptakan sesuatu yang baru, baik berupa produk atau gagasan baru yang dapat diterapkan dalam memecahkan masalah, atau sebagai kemampuan untuk melihat unsur-unsur yang sudah ada sebelumnya. Kreativitas adalah sebagai kemampuan yang berhubungan dengan kelancaran berpikir 
(fluency), kemampuan untuk mengembangkan, memperkaya, memperinci suatu gagasan (elaborasition), keaslian (originality), dan keluwesan (fleksibility)" (hal. 287-289). Organisasi ijma yang merupakan organisasi baru dengan bertujuan ingin memakmurkan masjid, sebagai wadah ukhuwah islamiah dan pengembangan remaja masjid dalam meningkatkan keimanan, ketakwaan, dan didasarkan atas kesadaran dan kewajiban serta tanggung jawab sebagai remaja masjid yang memiliki potensi ilmu pengetahuan dan dinamika yang melekat pada dirirnya sehingga menghasilkan suatu karakter yang baik dan dapat bermanfaat baik untuk diri sendiri, untuk kelompok, maupun untuk orang lain. Hal ini sejalan dengan Soedarsono (2008) yang mengatakan bahwa karakter harus diwujudkan melalui nilai-nilai moral yang dipatrikan untuk menjadi semacam nilai intrinsik dalam diri kita dan mewujud dalam suatu sistem daya juang yang akan melandasi pemikiran sikap dan perilaku kita. Karakter tentu tidak datang dengan sendirinya, melainkan harus kita bentuk, kita tumbuh kembangkan, dan kita bangun secara sadar dan sengaja.

Organisasi ijma merupakan organisasi yang terbentuk dari organisasi yang mempunyai keinginan bersama, dan tujuan yang sama melakukan perubahan terhadap kemakmuran masjid. Hal ini sejalan dengan pandangan Duha (2018) mengatakan bahwa "orgaisasi merupakan kesatuan yang terbentuk oleh beberapa orang yang memiliki sedikit atau semua kesamaan tentang latar belakang, identitas, harapan, dan berbagai hal lainnya untuk mencapai tujuan bersama secara bersama-sama" (hal. 2). Dengan melakukan kegiatan yang dulu pernah dilakukan dan sekarang dilakukan kembali yaitu seperti adanya pengajian ruti tetapi organisasi ijma disini memberikan nuansa baru dengan ide atau gagasan baru seperti memberikan hidangan makanan ringan dan minuman kopi agar para jamaah yang hadir tidak kantuk dan lebih semangat dalam beribadah. Sehingga mengkombinasikan kegiatan yang dulu pernah ada dengan sajian atau hidangan yang belum pernah dilakukan oleh organisasi sebelumnya. Hal ini sejalan dengan pandangan Affan (2015) mengemukakan bahwa sifat kreatif atau kreativitas pada intinya merupakan kemampuan seseorang untuk melahirkan sesuatu yang baru, baik berupa gagasan maupun karya nyata, baik dalam bentuk karya baru maupun kombinasi dari hal hal yang ada, yang semuanya itu relatif berbeda dengan apa yang telah ada sebelumnya.

Pengembangan karakter kreatif yang dilakukan ijma dalam suatu kegiatan mulai dari kalangan orang tua, pemuda maupun remaja diharuskan memberikan pemikiraan maupun ide ataupun membuat satu hal yang dapat dimanfaatkan mulai dari sebelum melakukan suatu kegiatan, dilakukannya musyawarah dengan membuat gebrakan yang berbeda, dan lebih bermanfaat untuk orang lain membuat perubahan baru dengan adanya kesenian dalam kegiatan ijma dimana kesenian disini yang ditampilkan oleh anggota remaja dengan alat musik yang disebut grup terbangan Alherryah bahkan alat musiknyapun pertama dibuat oleh anggota ijma dengan menggunakan viva bekas dan dipadukan dengan alat musik lainnya. Hal ini sejalan dengan Amirrudin (2015) mengatakan bahwa "cara berfikir kreatif merupakan cara yang dipenuhi ide atau gagasan baru dalam mengembangkan daya imajinasi. Pemikiran yang kreatif adalah pemikiran yang dapat menemukan hal-hal atau cara-cara baru yang berbeda dari biasanya dan pemikiran yang mampu mengemukakan ide atau gagasan yang memiliki nilai tambah atau bermanfaat" .

\section{Simpulan}

Sehingga dapat disimpulkan bahwa cara organisasi ijma mengimplementasikan karakter kreatif dalam kegiatan untuk memakmurkan masjid itu sangat baik. Terlihat ketika organisasi ijma menjalankan tugas mulai dari ketua samapai anggota remaja dengan mempunyai tugasnya masingmasing, bertujuan ingin melakukan perubahan dalam memakmurkan masjid mulai dari merencanakan kegiatan sampai langkah-langkah kegiatan apa yang akan dilakukan untuk mengimplementasikan karakter kreatif dalam memakmurkan masjid. Dengan kegiatan-kegiatan yang baru, berbeda dari sebelumnya tetapi tidak meninggalkan kegiatan yang dulu pernah dilakukan sehingga mengkombinasika kegiatan yang sudah ada tetapi di kemas dengan sesuatu yang berbeda, 
Mulai dari melakukan musyawarah, membuat kegiatan yang belum pernah dilakukan sebelumnya seperti melakukan pengajian rutin dengan dihidangkan makanan ringana, melakukan pementasan seni, membuat sesuatu hal yang dapat bermanfaat yang tadinya tidak terpakai menjadi terpakai seperti alat musik, dan membuat sesuatu yang dapat mengandung kekreatifan dalam memakmurkan masjid seperti membuat grup terbangan dengan belajar bersama-sama seminggu sekali, bekerjasama dengan organisasi lain dalam memajukan agama khusunya di lingkungan masyarakat.

\section{Referensi}

Affan, F. 2015. Pembelajaran Seni Kriya Topeng Sebagai Pembentukan Karakter Kreatif Siswa Kelas XI IPA 1 SMA N 5 TEGAL. Skripsi. Program Studi Jurusan Seni Rupa Fakultas Bahasa Dan Seni Universitas Negeri Semarang.

Ali, M. A. 2018. Pendidikan Karakter Konsep dan Implementasi. Jakarta : Penerbit Kencana Prenadamedia Group

Amirrudin, N. 2015. Membangun Pendidikan Berbasis Karakter Kreatif Dalam Bingkai ISMUBA SMK Muhammadiyah 2 Palembang. Skripsi. Palembang: Program Studi Tarbiyah Pendidikan Agama Islam Fakultas Agama Islam Universitas Muhammadiya Palemang.

Duha, T. 2018. Perilaku Organisasi. Yogyakarta : Penerbit DEEPUBLISH (Grup Penerbitan CV BUDI UTAMA)

Gifhar, R. dkk. 2019. Meningkatkan Kreativitas Guru Melalui Pengembangan Supervisi Kepala Sekolah Dan Iklim Organisasi. Jurnal Manajemen Pendidikan Voll 7 Nom 2 hlm 79

Kurnia, S. D.2015. Pengaruh Kegiatan Painting Dan Ketrampilan Motorik Halus Terhadap Kreativitas Anak Usia Dini Dalam Seni Lukis. Jurnal Pendidikan Usia Dini Voll 9 No 2 hl 287-289

Puhantara, W. 2012. Menciptakan Organisiasi Yang Kreatif. Jurnal Economia Voll 8 No 2 hlm 154-155

Soedarsono, S. 2008. Membangun Kembali Jati Diri Bangsa Peran Penting Karakter dan Hasrat untuk Berubah. Jakarta: PT Elex Media Komputindo

Sugiyono. 2014. Metode Penelitian Kuantitatif Kualitatif Dan R\&D. Bandung: Alfabeta 